\title{
Clinico-radiological Features and Classification of Emphysematous Pyelonephritis: A prospective study
}

\section{Singh A}

Department of Radiodiagnosis, Government Medical College, Amritsar, Punjab, India

\begin{abstract}
Emphysematous pyelonephritis (EPN) is a rare, severe acute, necrotizing infection of the kidney characterized by presence of gas within the renal parenchyma, collecting system and perirenal tissues. It is commonly caused by ascending infection due to E.coli. Other gas forming organisms like Klebseilla, proteus etc. may spread by hematogenous route. A patient especially if a woman, with poorly managed diabetes, presents with urinary tract infection, sepsis and renal insufficiency. Ultrasound and CT plays an invaluable role in the diagnosis and management. In our study, nine patients of EPN were studied during the period of 20112013. All the patients were diabetics, invariably presented with fever, abdominal discomfort or pain at the time of presentation. Pus in urine with raised TLC with leukocytosis was seen in all of them. Urine culture showed bacterial growth in 5(55.5\%) patients, with E. coli, the commonest organism. All patients had hyperglycemia with mean blood sugar level was $354 \mathrm{mg} / \mathrm{dl}$. Serum creatinine was raised with mean level of $3.7 \mathrm{mg} / \mathrm{dl}$ suggesting renal dysfunction. The male to female ratio was 1:3.5 with age range of 42-65 years. Radiological investigations like plain X ray, Ultrasound and Computed tomography of abdomen showed pockets of air in the renal regions in all 9(100\%)patients, bilateral in two(22.3\%) and unilateral in $7(77.7 \%)$ patients. Mild hydronephrosis was seen in 1(11\%) patient. Perinephric extension of gas with perinephric collection was noted in $4(44.5 \%)$ patients. After clinicoradiological investigations the diagnosis of EPN was made with 2(22.3\%) cases of Type I EPN and 7(77.7\%) cases of Type II EPN.
\end{abstract}

Keywords: Emphysematous pyelonephritis, Diabetes, Radiological findings.

\section{Introduction}

Emphysematous pyelonephritis (EPN) is a life-threatening necrotizing gas forming infection of the kidneys and its surrounding

Corrospondence to: Dr. Arvinder Singh, Associate Professor, Government medical college, Amritsar, Punjab, India.

Email:- arvinderdr@ rediffmail.com tissues. Approximately $90 \%$ of patients are diabetes, while non-diabetic patients are either immune-compromised or have associated urinary tract obstruction secondary to calculi or neoplasm. The most common organisms involved are E coli, Klebsiella pneumonia, and Proteus mirabilis. Since this condition rapidly progressive to fulminant sepsis, early diagnosis and 


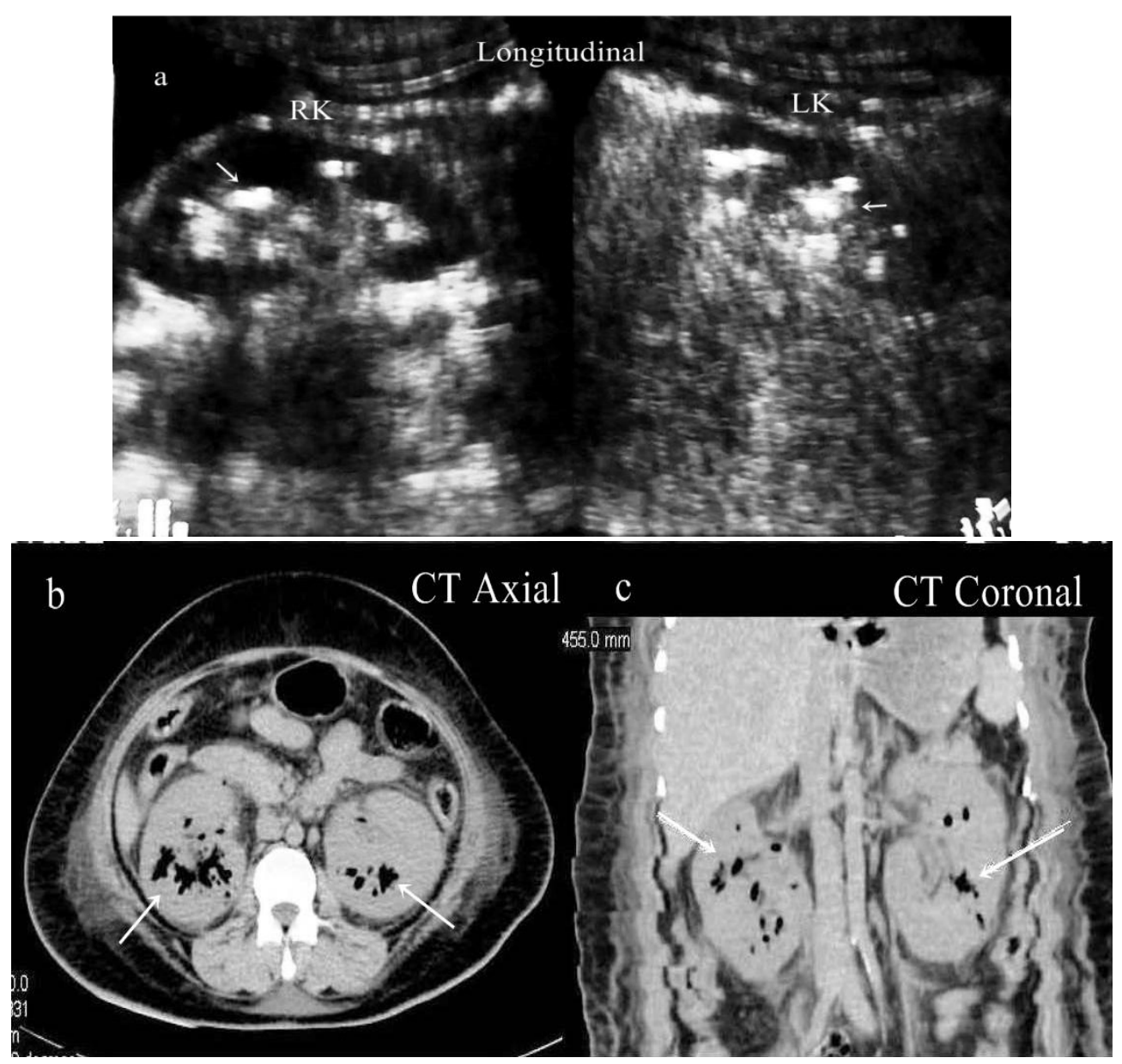

Fig 1: Bilateral Types 1 EPN. (a)Ultrasound showing focal echogenic areas with posterior dirty shadowing involving parenchyma of both the kidney.(b,c)Axial and sagittal CT scan showing small areas of gas attenuation areas involving parenchyma of both the kidneys(white arrows). Both kidneys are enlarged with absence of fluid in or around the kidney.

treatment of causative factors reduces high degree of morbidity and mortality. ${ }^{1}$

The conventional $\mathrm{X}$ ray examination shows "mottled" appearance due to air pockets in the renal fossa or perirenal gas collections within the Gerota fascia (Fig.2a, 4a).

Ultrasound is initial imaging modality because of its easy availablity, high diagnostic accuracy, and lack of radiation. The renal parenchymal gas on ultrasound appear as areas of echogenic foci with posterior 'dirty' shadowing or ringing down artifacts due to air, in a non-dependent position which may change with patient posture (Fig1a,2b). Such echogenic foci should be differentiated from renal stones, which are mostly echogenic in nature have posterior acoustic shadowing which have clean margins. Gas may be present inside the collecting system in emphysematous pyelitis. $^{2}$

Computed Tomography is an investigation of choice in patients with emphysematous pyelonephritis. It can exactly and accurately define the extent of disease, localization of air pockets hence helps in classifying the disease. The various findings on CT may be 

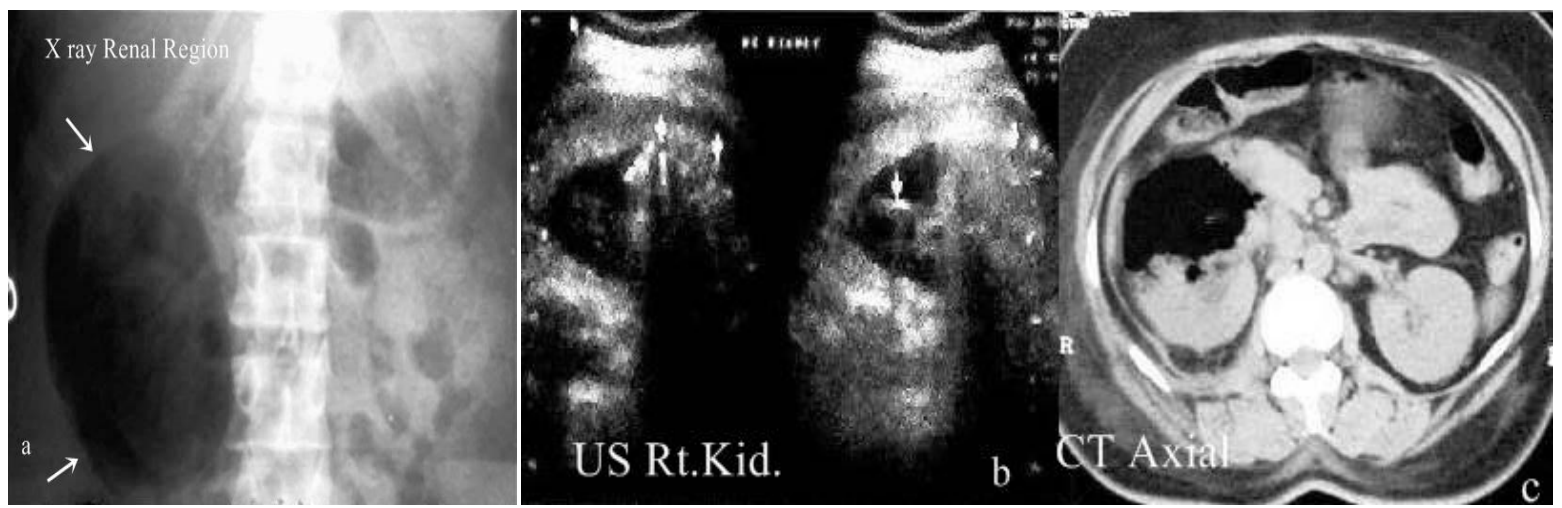

Fig 2: Unilateral Types 2 EPN. (a) Plain $X$ ray showing a large pocket of air in reniform pattern occupying the right renal area. Some amount of renal tissue can be seen through it.(b)Ultrasound of same patient showing echogenic areas with posterior dirty shadowing obscuring the renal region. Small pocket of air is also seen in the upper calyx.(c) CT scan demonstrates type 2 emphysematous pyelonephritis, which appears as a large area of air that has completely destroyed the anterior cortex of the right kidney with contour distortion. Note the absence of fluid within or around the kidney.

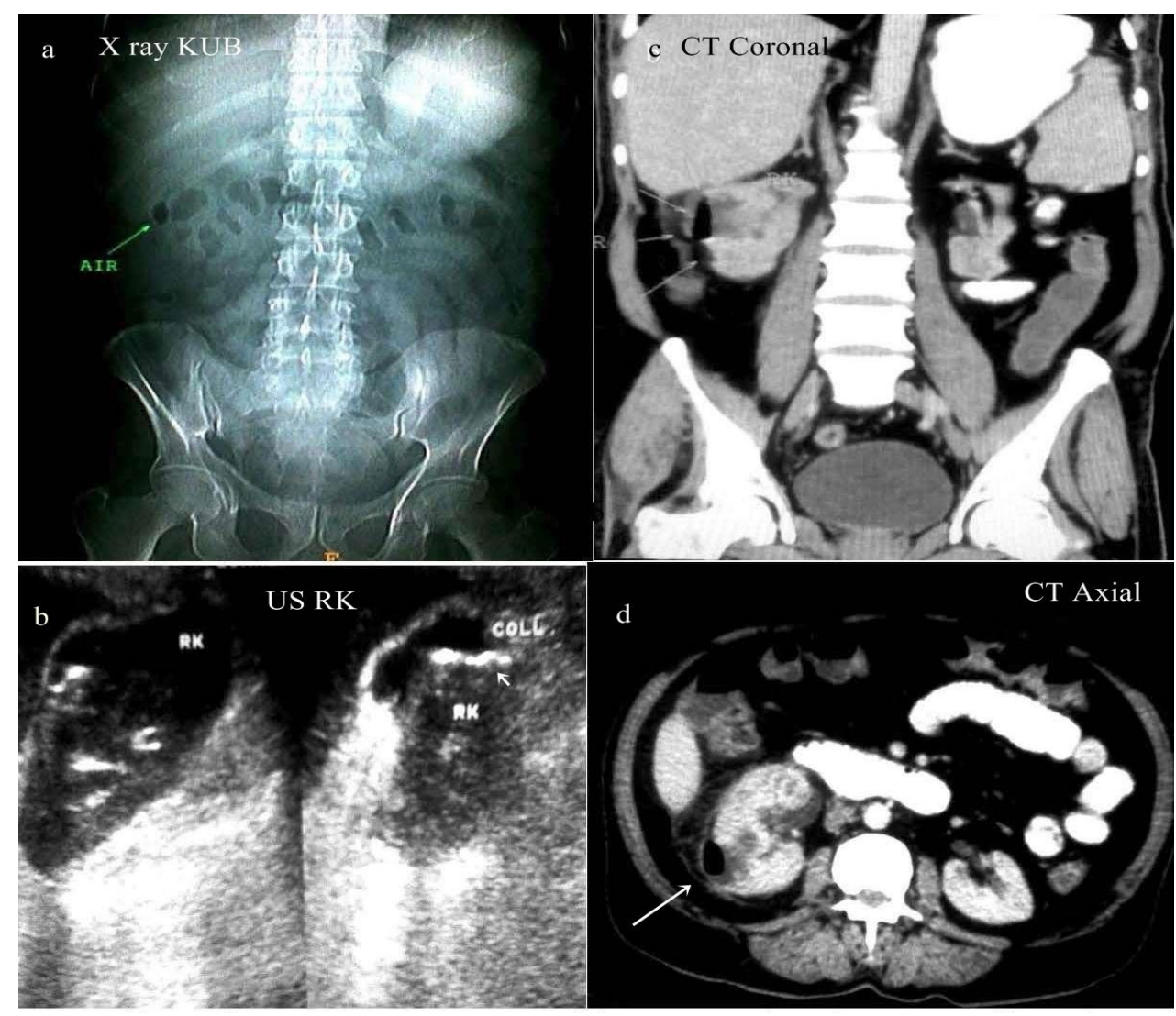

Fig 3: Unilateral Types 2 EPN. (a)Plain $X$ ray showing a small pocket of air in right renal region (arrow)(b)Ultrasound of same patient showing an irregular echogenic areas with dirty acoustic shadowing. Significant perinephric collection is also $\operatorname{seen}(c, d)$ Coronal and axial CT scan showing a small pocket of air in subcapsular region(long arrows) with perinephric collection, with contour distortion. Ill defined hypodensities are seen in renal parenchyma indicative of intraparenchymal abscesses. 

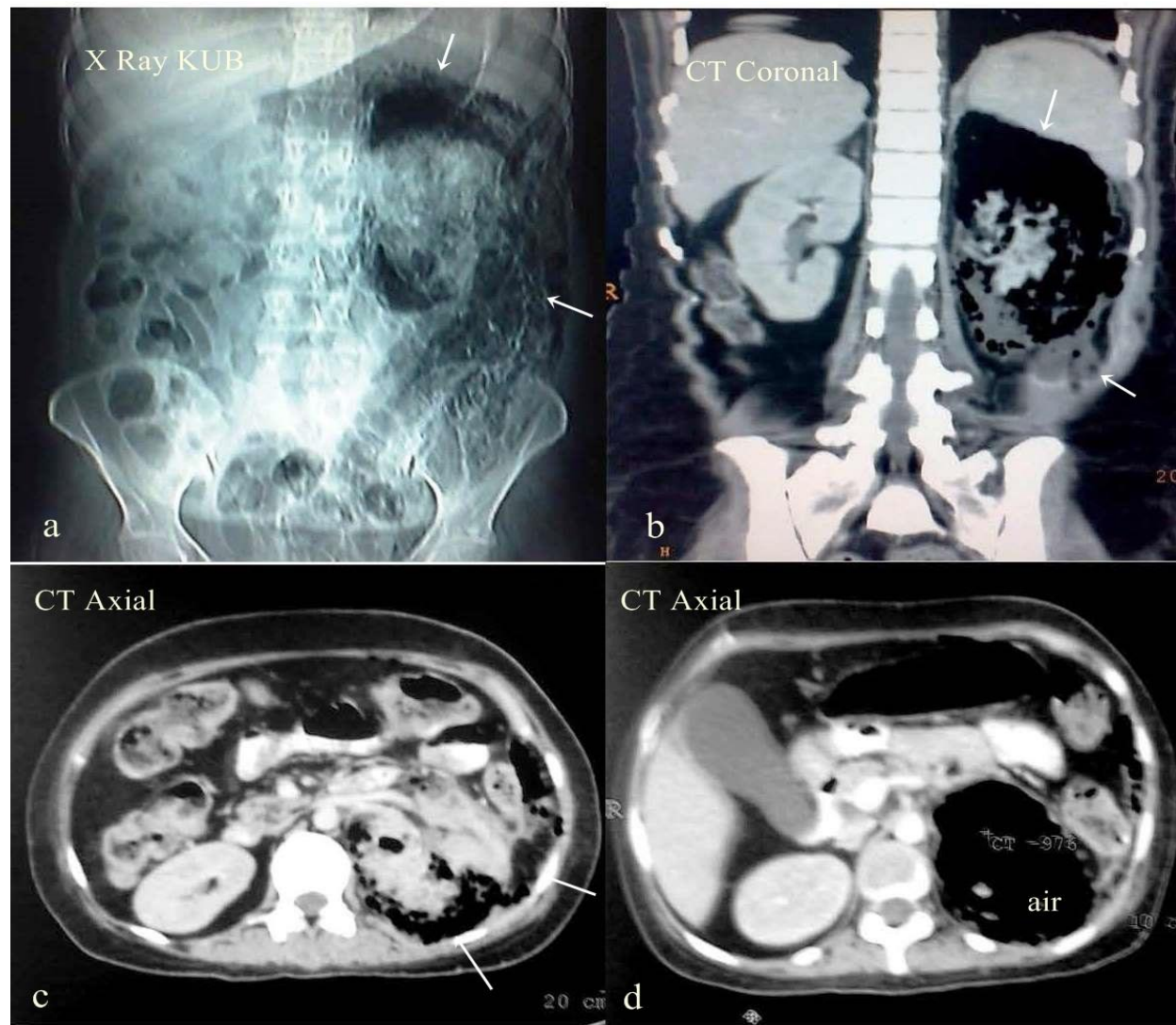

Figure 4: Unilateral Types 2 EPN. (a)Plain $X$ ray showing marked mottling due to extensive air pockets in the left renal region without visualization of normal renal tissue.(b,c,d)Coronal and axial CT sections showing marked mottling in left renal region extending into perinephric and posterior pararenal space(arrows). Normal renal tissue shows amorphous mass like structure suggestive of complete renal destruction by EPN with extensive pararenal necrotizing cellulitis.

renal parenchymal enlargement and destruction, small pockets of air with linear streaks of gas, perirenal fluid collections, and focal areas of tissue necrosis with or without abscess formation.

Based on CT findings Wan et $\mathrm{al}^{1}$ classified emphysematous pyelonephritis into two types, according to distribution of the gas and its correlation with prognosis. Type I emphysematous pyelonephritis is characterized by renal parenchymal destruction that manifests with either streaky or mottled areas of gas attenuations. No perirenal fluid collections are noted (Fig.1). Type II emphysematous pyelonephritis is characterized by intrarenal or perirenal fluid collections associated with loculated gas or gas within the urinary collecting system (Fig $2,3,4)$. Type 1 EPN disease has a more aggressive clinical course, with higher incidence of mortality of $69 \%$ as compared to Type 2 EPN with mortality of about $18 \%$. However, diagnosis at an early stage, aggressive medical treatment along with percutaneous drainage and partial or complete nephrectomy yields better results with reducing of mortality rates. ${ }^{3,7}$

\section{Rationale \& Objectives}

The rationale behind this study was to diagnose the cases of Emphysematous Pyelonephritis at an early stage by clinical 
Table 1: Showing the clinical,biochemical findings and outcome.

\begin{tabular}{|c|c|c|c|c|c|c|c|c|c|c|c|}
\hline 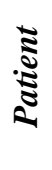 & $+\infty$ & ڤัँ & 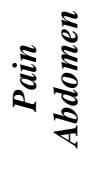 & ঠे & 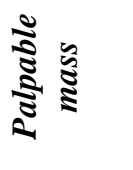 & हैँ & 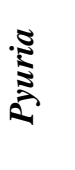 & 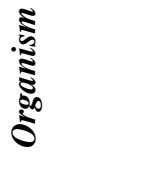 & $\underset{\Xi}{U}$ & 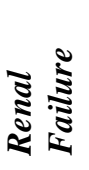 & 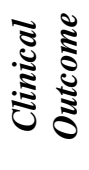 \\
\hline 1 & 60 & $\mathrm{~F}$ & Present & Present & - & Present & ++ & - & Raised & - & - \\
\hline 2 & 45 & $\mathrm{~F}$ & Present & Present & Present & Present & + & E.coli & Raised & ++ & Died \\
\hline 3 & 48 & $\mathrm{~F}$ & Present & Present & - & Present & + & - & Raised & - & - \\
\hline 4 & 45 & $\mathrm{~F}$ & Present & Present & Present & Present & +++ & Klebseilla & Raised & +++ & Died \\
\hline 5 & 60 & M & Present & Present & Present & Present & ++ & E.coli & Raised & ++ & - \\
\hline 6 & 42 & $\mathrm{~F}$ & Present & Present & - & Present & ++ & - & Raised & - & - \\
\hline 7 & 65 & $\mathrm{~F}$ & Present & Present & Present & Present & ++ & E.coli & Raised & ++ & - \\
\hline 8 & 58 & $\mathrm{~F}$ & Present & Present & - & Present & ++ & E.coli & Raised & - & - \\
\hline 9 & 50 & M & Present & Present & - & Present & + & - & Raised & - & - \\
\hline
\end{tabular}

assessment especially in poorly controlled diabetics and judicious selection of such patients for various imaging modalities. Also with advent of high resolution sonography and Computed Tomography we manage to classify the disease, so as to reduce high mortality associated with the disease.

\section{Material and Methods}

During the period 2011-2013, eight patients with gas producing renal parenchymal infection that met the criteria of clinical manifestations of fever, local pain or tenderness in loin region, pyuria and imaging findings of gas in renal parenchyma, collecting system or perirenal space. Sonography was done with Toshiba and Esoatecolor Doppler machine using 3.5 Mhz transducer. Computed tomography was done using MDCT 190T Philips Scanner axial sections with coronal and sagittal reformats. The clinical manifestations and radiological findings in form of ultrasonography and Computed Tomography were reviewed and final diagnosis of EPN along with classification was made.

\section{Results}

Nine patients were studied during the period of March 2011 to January 2013.The results were drawn in tabulated form and following inference were made.

In our study of nine patients, the male to female ratio was 1:3.5 with age range of 4265 years. The disease was common in female $7(77.7 \%)$ patients and in male $2(22.3 \%)$. The clinically examination showed fever \& abdominal discomfort or pain at the time of presentation in all nine patients. Palpable loin mass was seen in only $4(44.5 \%)$ patients. Routine urine indicated pyuria in all nine $(100 \%)$ patients. Urine culture showed bacterial growth in $5(55.5 \%)$ patients, with E.Coli as the commonest organism in 4 (44.5\%) patients and Klebsiella in only one (11\%) patient. Total Leucocyte Count was also raised in all $9(100 \%)$ cases with evidence of leukocytosis. All the nine $(100 \%)$ patients were known diabetics and were on medication at variable stage of disease. They were hyper glycemic with mean blood sugar $354 \mathrm{mg} / \mathrm{dl}$. Serum creatinine was raised in $4(44.5 \%)$ patients 
Table 2: Showing the various radiological findings on plain X Ray,Ultrasound and CT Abdomen

\begin{tabular}{|c|c|c|c|c|c|c|c|}
\hline \multirow[t]{2}{*}{ Patient } & \multirow{2}{*}{$\begin{array}{l}\text { Causative } \\
\text { Factor }\end{array}$} & \multirow{2}{*}{$\begin{array}{l}\text { Plain X Ray } \\
\text { Findings }\end{array}$} & \multicolumn{2}{|l|}{ US Findings } & \multicolumn{2}{|l|}{ CT Findings } & \multirow[t]{2}{*}{ EPN Type } \\
\hline & & & Right & Left & Right & Left & \\
\hline 1 & $\begin{array}{l}\text { Diabetes, } \\
\text { Calculus }\end{array}$ & $\begin{array}{l}\text { Air pockets } \\
\text { Rt renal area }\end{array}$ & $\begin{array}{l}\text { Echogenic foci with } \\
\text { dirty shadowing due } \\
\text { to air, Calculi Rt PCS }\end{array}$ & - & $\begin{array}{l}\text { Pockets of air ,calculus Rt } \\
\text { PCS }\end{array}$ & - & $\begin{array}{l}\text { Unilateral } \\
\text { Type II EPN }\end{array}$ \\
\hline 2 & Diabetes & $\begin{array}{l}\text { Air pockets in } \\
\text { Bilateral Renal } \\
\text { areas }\end{array}$ & $\begin{array}{l}\text { Echogenic foci Renal } \\
\text { tissue }\end{array}$ & $\begin{array}{l}\text { Echogenic foci } \\
\text { Renal tissue }\end{array}$ & $\begin{array}{l}\text { Air pockets } \\
\text { Renal parenchyma }\end{array}$ & $\begin{array}{l}\text { Air pockets } \\
\text { Renal } \\
\text { parenchyma }\end{array}$ & $\begin{array}{l}\text { Bilateral } \\
\text { Type I EPN }\end{array}$ \\
\hline 3 & Diabetes & $\begin{array}{l}\text { Air in left renal } \\
\text { region }\end{array}$ & - & $\begin{array}{l}\text { Intraparenhymal } \\
\text { Echogenic foci } \\
\text { with collection }\end{array}$ & - & $\begin{array}{l}\text { Air pocket } \\
\text { with } \\
\text { Renal abscess }\end{array}$ & $\begin{array}{l}\text { Unilateral } \\
\text { Type I EPN }\end{array}$ \\
\hline 4 & Diabetes & $\begin{array}{l}\text { ReniformAir } \\
\text { replacing right } \\
\text { renal area }\end{array}$ & $\begin{array}{l}\text { Echowindow poor } \\
\text { with obscured renal } \\
\text { pelvis }\end{array}$ & - & $\begin{array}{l}\text { Rt. renal } \\
\text { Parenchymal,perinephric air } \\
\text { pockets }\end{array}$ & - & $\begin{array}{l}\text { Unilateral } \\
\text { Type II EPN }\end{array}$ \\
\hline 5 & Diabetes & $\begin{array}{l}\text { Small air in } \\
\text { Rt Renal area }\end{array}$ & $\begin{array}{l}\text { Subcapsular air, with } \\
\text { perinephric collection }\end{array}$ & - & $\begin{array}{l}\text { Small pocket of intra } \\
\text { renal air with perinephric } \\
\text { collection }\end{array}$ & - & $\begin{array}{l}\text { Unilateral } \\
\text { Type II EPN }\end{array}$ \\
\hline 6 & Diabetes & $\begin{array}{l}\text { Mottling in left } \\
\text { renal area }\end{array}$ & - & $\begin{array}{l}\text { Echogenic foci } \\
\text { Renal PCS and } \\
\text { perirenal areas }\end{array}$ & - & $\begin{array}{l}\text { Left renal and } \\
\text { PCS replaced } \\
\text { by large } \\
\text { amount of } \\
\text { perirenal air }\end{array}$ & $\begin{array}{l}\text { Unilateral } \\
\text { Type II EPN }\end{array}$ \\
\hline 7 & Diabetes & $\begin{array}{l}\text { Single air pocket } \\
\text { Rt renal area }\end{array}$ & $\begin{array}{l}\text { Echogenic foci upper } \\
\text { calyx }\end{array}$ & - & Air pocket in upper calyx & - & $\begin{array}{l}\text { Unilateral } \\
\text { Type II EPN }\end{array}$ \\
\hline 8 & Diabetes & $\begin{array}{l}\text { Air Mottling right } \\
\text { upper } \\
\text { pole }\end{array}$ & $\begin{array}{l}\text { Echogenic foci upper } \\
\text { pole region }\end{array}$ & - & $\begin{array}{l}\text { Intrarenal air with } \\
\text { perinephric collection }\end{array}$ & - & $\begin{array}{l}\text { Unilateral } \\
\text { Type II EPN }\end{array}$ \\
\hline 9 & Diabetes & $\begin{array}{l}\text { Air } \\
\text { MottlingBilateral } \\
\text { renal areas }\end{array}$ & $\begin{array}{l}\text { Echogenic foci renal } \\
\text { calyces }\end{array}$ & $\begin{array}{l}\text { Echogenic foci } \\
\text { renal calyces }\end{array}$ & Air pockets renal calyces & $\begin{array}{l}\text { Air pockets } \\
\text { renal calyces }\end{array}$ & $\begin{array}{l}\text { Bilateral } \\
\text { Type II EPN }\end{array}$ \\
\hline
\end{tabular}


with mean serum creatinine level of $3.7 \mathrm{mg} / \mathrm{dl}$ suggesting renal dysfunction.

In our study of nine patients, the various findings on imaging were as follow. All the nine $(100 \%)$ patients were diabetics, with only one (11\%) having calculus impacted causing obstruction. Plain $\mathrm{X}$ ray abdomen showed air/air pockets in single or both renal regions, though bowel gas can overlap the renal areas. Ultrasound showed echogenic foci with dirty shadowing localized to renal parenchyma, pelvicalyceal system and/or perinephric extension with perinephric collections. Calculus was seen in only one case with sharp posterior acoustic shadowing making the diagnosis of impacted stone. Computed tomography (CT) abdomen showed pockets of air in the renal regions in all $9(100 \%)$ patients. The disease was bilateral in $2(22.3 \%)$ patients and unilateral in $7(77.7 \%)$ patients. Mild hydronephrosis was seen in $1(11 \%)$ patient due to impacted calculus. Perinephric extension of gas with perinephric collection was noted in $4(44.5 \%)$ patients, with one patient having extensive pockets of air with fluid collections due to extension of disease in perinephric and posterior paranephric spaces.

After clinic-radiological investigations the diagnosis of EPN was made with 2(22.3\%) cases of Type I EPN and 7(77.7\%) cases of Type II EPN.

The final clinical outcome of the disease was that with early clinico-radiological investigations $7(77.7 \%)$ patients recovered completely, and $2(22.3 \%)$ patients died due to severe Type I EPN and its complications.

\section{Discussion}

EPN is an acute necrotizing renal parenchymal and perirenal infection caused by gas forming organisms. Guiard noted the association between diabetes mellitus and this entity. ${ }^{4}$ Sehultz and Klorefein were the first to use the term EPN to describe this entity. ${ }^{1}$ It is common in female, diabetics, debilitated and immune compromized. E. Coli is the commonest causative organism, others being proteus, klebsiella, anaerobic streptococcus, candida and cryptococcus. In our study, E.coli was common organism cultured in $4(44.5 \%)$ cases followed by Klebseilla in one (11\%).

The micro-organisms cause fermentation of glucose leading to formation of gases like Carbon dioxide, Nitrogen, Hydrogen, Oxygen and Methane. Urinary tract obstruction and renal vascular supply impairment add to the ongoing processes. 5,6,7 Abdominal pain (50\%) and vomiting $(40 \%)$ are common symptoms. Fever is seen in about $80 \%$. Abdominal tenderness is common, but palpable mass may or may not be there. Pyuria and leukocytosis are commonly reported in EPN. 5,6

In our study, abdominal discomfort/ pain, fever was noted in all 9(100\%) patients. Palpable mass in renal region was noted in $4(44.5 \%)$ cases. Pyuria and leukocytes were seen in all $9(100 \%)$ cases.

In our study, fever, abdominal pain/discomfort was noted in all the cases, palpable abdominal mass in $4(44.5 \%)$ patients. Leukocytosis and pyuria were found in all nine patients. Urine culture grew the organism in $5(55.5 \%)$ patients. E.Coli was the commonest organism in $4(44.5 \%)$ 
followed by Klebsiella. Hyperglycemia was present in all with raised serum creatinine in 4 patients at presentation.

Plain X-Ray may reveal mottled areas of gas shadow in the renal regions or a cresent of perinephric gas. Ultrasound shows echogenic shadows. Poor echo window due to bowel gas and obesity may hinder with plain X-Ray and ultrasound interpretations.

In our study, plain X-ray showed air in the renal parenchyma nearly in all the cases. Ultrasound gave suggestion for presence of gas in renal parenchyma or perinephric spaces. ${ }^{8} \quad$ Computed tomography is investigation of choice and plays a vital role in diagnosis, classification and management of EPN. Type I EPN is characterized by parenchymal destruction with absence of fluid collection and presence of streaky or mottled gas. Type II EPN is characterized by renal or perirenal fluid collections with pockets of loculated gas or gas in the collection system. Type IEPN is associated with more extensive parenchymal necrosis and fulminant clinical course than Type II . ${ }^{1,7}$

In our study, Computed tomography (CT) abdomen showed pockets of air in the renal regions in all $9(100 \%)$ patients. The disease was bilateral in $2(22.3 \%)$ patients and unilateral in $7(77.7 \%)$ patients. Perinephric extension of gas with perinephric collection was noted in $4(44.5 \%)$ patients. CT was able to classify the EPN, with $2(22.3 \%)$ cases of Type I EPN and $7(77.7 \%)$ cases of Type II EPN

EPN was shown to be associated with high mortality $(80 \%)$. Early diagnosis with various imaging modalities especially Computed Tomography help reduce the overall morbidity and mortality. Treatment of the causative factor whether poorly managed diabetes mellitus or obstruction due to calculus or growth should be treated as early as possible. Impaired renal function, Type I EPN and poorly managed diabetes have poor outcome. ${ }^{9}$

In our study, the mortality rate was in $2(22.3 \%)$ which was quite less as compared to other studies due to early diagnosis and management.

\section{Conclusion}

Emphysematous pyelonephritis is an acute necrotizing renal parenchymal and perirenal infection caused by gas forming organisms. It has poor outcome and is associated with high mortality up to $80 \%$. With advent of sonography and computed tomography along with clinical correlation the mortality has over the time reduced to about $18-20 \%$. Hence early diagnosis of EPN especially Type I in poorly managed diabetics, helps reduce mortality to a larger extent.

\section{References}

1. Wan YL, Lee TY, Bullard MJ and Tsai CC. Acute gas producing bacterial renal infection: Correlation between imaging findings and clinical outcome. Radiology 1996; 198:433-438.

2. SY Hui, CW Cheung, KT Hui, HL She. Sonographic diagnosis of emphysematous pyelonephritis in a clinically stable patient. Hong Kong Med J 2010;16(4):139.

3. Grayson DE, Abbott RM, Levy AD, Sherman PM. Emphysematous infections 
of the abdomen and pelvis: a pictorial review. RadioGraphics 2002;22:543561.

4. Alasdair D, Mackie R, Drury PL: Urinary tract infection in diabetes mellitus, in infections of the kidney and urinary tract, ed. Cattell WR, Oxfprd, Oxford Medical Publications, 1996 p.219233.

5. Ho KMT, Sole GM. Pneumaturiadut to gas producing organism E.coli and urinary stasis. British $\mathrm{J}$ of Urol 1994:73:588-589.

6. Aravind C, Talwalkar NC. Renal emphysema. JAssoc of Physicians India 1997; 45:739-740.

7. JJ Huang, CC Tseng. Emphysematous pyelonephritis. Clinico-radiological classification, management, prognosis and pathogenesis. Arch Intern Medicine 2000;160:797-805.

8. Verma A, Srivastava A, Varma DN, Sharma OP. Radiologyquiz: Uroradiology. Indian Journal of Radiology and Imaging 2002;12(2):291292.

9. Wan YL, Lo SK, Bullard MJ, Chang PL, Lee TY. Predictors of outcome in Emphysematous Pyelonephritis. The J Urol 1998;159:369-373. 